\title{
Investigating the effects of organizational justice on development of e-banking
}

\author{
Hamed Abbasi ${ }^{a}$, Hamid Reza Abbasi ${ }^{\mathrm{b}}$, Mahsan Hajirasouliha ${ }^{\mathrm{c}}$ and Ashkan Faraji ${ }^{\mathrm{c}}$
}

\author{
CHRON I C L E \\ Article history: \\ Received July 28, 2013 \\ Accepted 14 January 2014 \\ Available online \\ February 272014 \\ Keywords: \\ e-banking \\ Organizational justice \\ Distributive justice \\ Procedural justice \\ Interactional justice
}

${ }^{a}$ Department of Management, Tehran Central Branch, Islamic Azad University, Central, Iran

${ }^{b}$ Department of Management, Abhar Branch, Islamic Azad University, Abhar, Iran

${ }^{c}$ Department of Management and Accounting, South Tehran Branch, Islamic Azad University, Tehran, Iran

\section{A B S T R A C T}

This paper investigates the effects of three components of organizational justice on development e-banking in one of Iranian banks. The proposed study uses two questionnaires, one for measuring the effects of organizational justice and the other for e-banking in Likert scale. Cronbach alphas for organizational justice and e-banking are calculated as 0.831 and 0.749 , respectively. The study has been implemented among 385 regular customers of an Iranian bank. Using Spearman correlation ratio as well as stepwise regression analysis, the study has detected that two components of organizational justice including distributive justice and procedural justice influence on e-banking, positively.

\section{Introduction}

Organizational justice is conceptualized as a multi-dimensional construct with different components such as distributive, procedural and interpersonal justice. Barsky et al. (2011) stated the relative importance of affect and emotion in the appraisal of the fairness of a situation as well as one's attitudinal reactions to some circumstances. A myriad of literature in the organizational psychology field has investigated organizational justice as well as the associated outcomes. Perceptions of justice impact different key organizational outcomes such as motivation (Latham \& Pinder, 2005) and job satisfaction (Al-Zu'bi, 2010). There are different classifications for organizational justice and one of them consists of three components including distributive, procedural, and interactional justice, which includes informational and interpersonal justice. Distributive justice can be conceptualized as the fairness related to decision outcomes and distribution of resources, which could be tangible or intangible (Adams, 1963, 1965). Procedural justice can be described as the fairness of the processes, which could lead to various outcomes. When an individual feels that he/she has a voice in the process or that the process involves characteristics such as consistency, accuracy, ethicality, and lack of bias

*Corresponding author.

E-mail addresses: ashkan.faraji1367@gmail.com (A. Faraji) 
then procedural justice is accomplished (Leventhal, 1980). Interactional justice is associated with the treatment that an individual receives and can be promoted by enhancing explanations for decisions and delivering the news with sensitivity and respect (Bies \& Moag, 1986; Bies \& Shapiro, 1988). A construct validation study by Colquitt (2001) implies that interactional justice ought to be broken into two parts of interpersonal and informational justice. Interpersonal justice is associated with perceptions of respect and propriety in one's treatment while informational justice is associated with the adequacy of the explanations given in terms of their timeliness, specificity, and truthfulness.

\section{The proposed study}

This paper investigates the effects of three components of organizational justice on development ebanking in one of Iranian banks. The proposed study uses two questionnaires, one for measuring the effects of organizational justice and the other for e-banking in Likert scale. The proposed study considers the following three hypotheses,

1. Distributive justice influences on e-banking positively.

2. Procedural justice influences on e-banking positively.

3. Interactional justice influences on e-banking positively.

Fig. 2 shows the structure of the proposed study as follows,

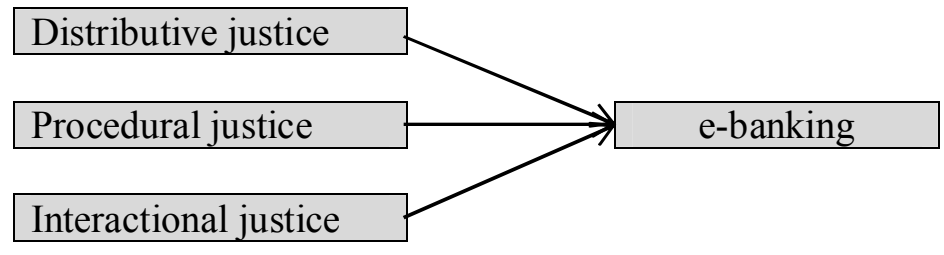

Fig. 2. The proposed study

Cronbach alphas for organizational justice and e-banking are calculated as 0.831 and 0.749 , respectively. The study has been implemented among 385 regular customers of an Iranian bank. The sample size is calculated as follows,

$N=Z_{\alpha / 2}^{2} \frac{p \times q}{e^{2}}$,

where $N$ is the sample size, $p=1-q$ represents the probability, $z_{\alpha / 2}$ is CDF of normal distribution and finally $\varepsilon$ is the error term. For our study we assume $p=0.5, z_{\alpha / 2}=1.96$ and $e=0.05$, the number of sample size is calculated as $N=385$. We have distributed the questionnaires among some participants and Fig. 3 demonstrates personal charactersitcs of the participants.

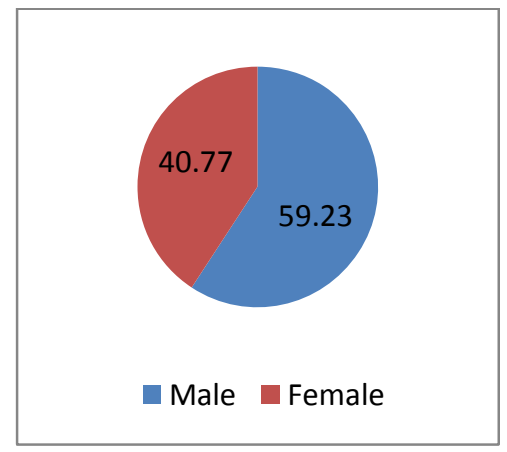

Gender

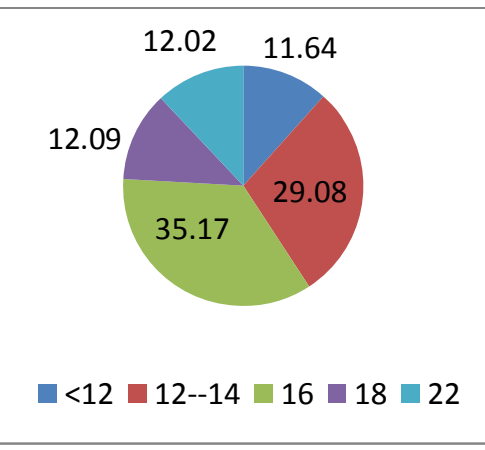

Years of education

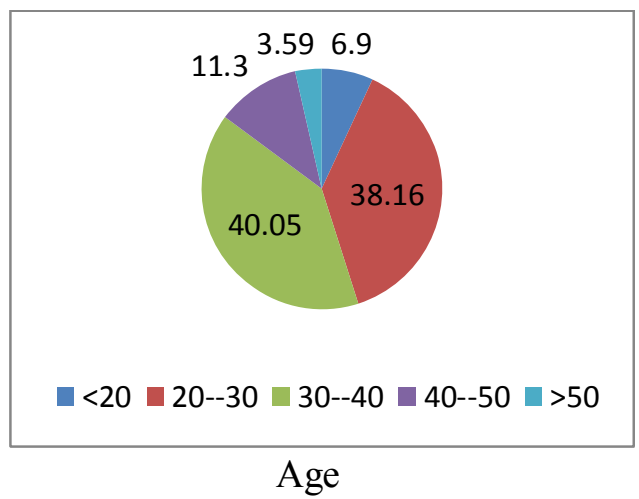

Age

Fig. 3. Personal characteristics of the participants 
As we can observe from the results of Fig. 3, nearly $60 \%$ of the participants were male. In terms of educational background, most participants maintained some university background. Finally, the survey indicates that most people who took part in our survey were middle aged people. The implementation of Kolmogorov-Smirnove test implies the data are not normally distributed. Therefore, we use Spearman correlation ratio as well as Stepwise regression test to verify the hypotheses of the survey.

\section{The results}

In this section, we present details of our findings on testing three hypotheses of the survey. Table 1 shows details of the results of Spearman correlation ratio on examining the impacts of three organizational justice on e-banking.

\section{Table 1}

The results of testing the effect of organizational justice on e-banking using Spearman correlation

\begin{tabular}{llccc}
\hline Hypothesis & Relationship & $\mathrm{r}$ & Sig. & Result \\
\hline First & Distributive justice $\rightarrow$ e-banking & 0.537 & 0.000 & Confirmed \\
Second & Procedural justice $\rightarrow$ e-banking & 0.284 & 0.023 & Confirmed \\
Third & Interactional justice $\rightarrow$ e-banking & 0.410 & 0.009 & Confirmed \\
\hline
\end{tabular}

The results of Table 1 clearly specify that there were positive and meaningful relationship between three components of organizational justice and e-banking when the level of significance is one percent. The highest correlation is between Distributive justice and e-banking $(r=0.537$, Sig. $=0.000)$ followed by the relationship between Interactional justice and e-banking $(r=0.410$, Sig. $=0.009)$ and between Procedural justice and e-banking $(\mathrm{r}=0.284$, Sig. $=0.023)$. We have also performed stepwise regression analysis and Table 2 shows the results of the survey.

\section{Table 2}

The summary of stepwise regression analysis

\begin{tabular}{lccccc}
\hline Variable & Coefficient & Standard error & Standard coefficient & t-value & P-value \\
\hline Intercept & 70.013 & 4.710 & & 23.715 & .000 \\
Distributive justice & .595 & .268 & .401 & 3.924 & .013 \\
Procedural justice & .321 & .135 & .249 & 2.301 & .008 \\
\hline
\end{tabular}

As we can observe from the results of Table 2, two organizational justice including distributive and procedural justice influence positively on e-banking $(\alpha=0.05)$.

\section{Conclusion}

In this paper, we have presented an empirical investigation to find the effects of organization justice on e-banking in Iranian banking industry. The study has distributed two questionnaires among some people and using Spearman correlation ratios as well as stepwise regression analysis, the study has determined that two organizational justice including distributive and procedural justice influence positively on e-banking $(\alpha=0.05)$. The results of this study are consistent with findings of McFarlin and Sweeney (1992), Masterson (2001), Tatum and Eberlin (2008) and Rupp et al. (2006).

\section{Acknowledgement}

The authors would like to thank the anonymous referees for their comments on earlier version of this paper. 


\section{References}

Adams, J. S. (1963). Towards an understanding of inequity. Journal of Abnormal and Social Psychology, 67, 422-436.

Adams, J. S. (1965). Inequity in social exchange. In L. Berkowitz: (Ed.), Advances in experimental social psychology (Vol. 2, pp. 267-299). New York: Academic Press.

Al-Zu'bi, H. A. (2010). A study of relationship between organizational justice and job satisfaction. International Journal of Business and Management, 5(12), 102-109.

Barsky, A., Kaplan, S. A., \& Beal, D.J. (2011). Just feelings? The role of affect in the formation of organizational fairness judgments. Journal of Management, 37, 248-279.

Bies, R. J., \& Moag, J. F. (1986). Interactional justice: Communication criteria of fairness. In R.J. Lewicki, B. H. Sheppard, \& M. H. Bazerman (Eds.), Research on negotiations in organizations (Vol. 1, pp. 43-55).Greenwich, CT: JAI Press.

Bies, R. J., \& Shapiro, D. L. (1988). Voice and justification: their influence on procedural fairness judgments. Academy of Management Journal, 31, 676-685.

Colquitt, J. A. (2001). On the dimensionality of organizational justice: A construct validation of a measure. Journal of Applied Psychology, 86, 386-400.

Latham, G. P., \& Pinder, C. C. (2005). Work motivation theory and research at the dawn of the twenty-first century. Annual Review of Psychology, 56, 485-516.

Leventhal, G. S. (1980). What should be done with equity theory? New approaches to the study of fairness in social relationship. In K. Gergen, M. Greenberg, \& R. Willis (Eds.), Social exchange: Advances in theory and research (pp. 27-55). New York: Plenum Press.

Masterson, S. S. (2001). A trickle-down model of organizational justice: relating employees' and customers' perceptions of and reactions to fairness. Journal of applied Psychology, 86(4), 594.

McFarlin, D. B., \& Sweeney, P. D. (1992). Research notes. Distributive and procedural justice as predictors of satisfaction with personal and organizational outcomes. Academy of management Journal, 35(3), 626-637.

Rupp, D. E., Ganapathi, J., Aguilera, R. V., \& Williams, C. A. (2006). Employee reactions to corporate social responsibility: An organizational justice framework. Journal of Organizational Behavior, 27, 537-543.

Tatum, B. C. \& Eberlin, R. J. (2008). The relationship between organizational justice and conflict style. Business Strategies Series, 9(6), 297-305. 